\title{
Mutations Affecting Aromatic Amino Acid Transport in Escherichia coli and Salmonella typhimurium
}

\author{
By GRACE M. THORNE* AND L. M. CORWIN \\ Department of Microbiology, Boston University School of Medicine, \\ Boston, Massachusetts 02118, U.S.A.
}

(Received 26 September 1974; revised 29 April 1975)

\section{SUMMARY}

A genetic locus, aroT, located between chr and the trp operon in Salmonella typhimurium, and similar genes, aroR and aroS; near the trp locus of Escherichia coli, were found to be involved in the transport of aromatic amino acids. Genetic lesions at these loci cause a variable diminution in uptake and accumulation of aromatic amino acids, alanine and glycine compared with the wild type. The $\mathrm{F}^{\prime}$ trp episome carries the aroR locus. Curing an $E$. coli strain of the $\mathrm{F}^{\prime}$ trp episome which covers a chromosomal deletion from $c y s B$ through the $\operatorname{trp}$ operon and $\operatorname{ton} B$ regions, results in a 60 to $80 \%$ decrease in tryptophan uptake. The introduction of $F^{\prime}$ trp into a trp operon-deleted $S$. typhimurium of low transport ability restores transport ability, suggesting that aroT in this organism may be homologous with aroR in $E$. coli. In $E$. coli, tryptophan accumulation is normally increased by prior growth in L-tryptophan, while in $S$. typhimurium it is repressed. In both genera, the trpR gene appears to have no effect on the tryptophan transport capabilities in response to changes in the concentration of L-tryptophan in the medium. Tryptophan transport in the $S$. typhimurium $\mathrm{F}^{\prime}$ trp hybrid was subject to repression, while in the $E$. coli strain which carries $\mathrm{F}^{\prime}$ trp covering the equivalent chromosomal deletion, an increase in tryptophan accumulation was shown after growth in L-tryptophansupplemented medium.

\section{INTRODUCTION}

In Escherichia coli $\mathrm{KI} 2$ and Salmonella typhimurium, the amino acid tryptophan is transported by two systems: a general aromatic transport system with $K_{m}$ about $\mathrm{I} \times \mathrm{IO}^{-7} \mathrm{M}$, and a specific non-inducible transport system for tryptophan with a $K_{m}$ of about I $\times 10^{-6} \mathrm{M}$ (Ames, 1964; Ames \& Roth, 1968; Piperno \& Oxender, 1968; Brown, 1970). A third inducible tryptophan transport system was reported in $E$. coli by Boezi \& DeMoss (196I) with a $K_{m}$ value for tryptophan of $\mathrm{I} \times 1 \mathrm{IO}^{-5} \mathrm{M}$. The latter system was absent under the growth conditions used in our study since it was repressed by the glucose in our growth medium. A genetic locus coding for a component of the general aromatic transport system (aroP) has been located. The relative gene order in the aroP region is leu-aziA-aroP-aceE in both $S$ typhimurium (Langley \& Guest, 1974) and E. coli (Guest, 1974). The genetic regions responsible for the three specific aromatic amino acid transport systems have not been found.

Increasing the concentration of tryptophan in the medium from 20 to $100 \mu \mathrm{g} / \mathrm{ml}$ enhances the growth of some slow-growing trp-chr deletion strains of $S$. typhimurium (Corwin et al. 1966). One possibility, that this effect was due to increased penetration of the required amino acid at the higher concentration, prompted a study of tryptophan transport in these strains. As a result, genetic lesions which result in lowered tryptophan transport were

* Present address: Infectious Diseases and Immunology Division, Department of Medicine, Medical University of South Carolina, Charleston, South Carolina 2940I, U.S.A. 


\section{Table I. Escherichia coli strains}

Strain

Genetic loci*

Source

\begin{tabular}{|c|c|}
\hline WI 485 & $\mathbf{F}^{-}$wild type \\
\hline T3 & $\operatorname{trp} E, \operatorname{tn} a A$ \\
\hline DBI & $\operatorname{trp} E, \operatorname{tn} a A$, aro $S$ \\
\hline $\mathrm{DBI} / \mathrm{F}^{\prime} \mathrm{trp}$ & 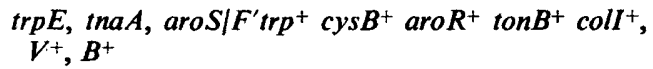 \\
\hline KYII 3 & $\begin{array}{l}\text { trp-ton } B \text {-cys } B \text {-aro } R \text { deletion } / \mathrm{F}^{\prime} \text { trp }^{+}, \text {coll }{ }^{+}, V^{+}, B^{+} \text {, } \\
\text { cys } B^{+}, \text {aro } R^{+}, \text {ton } B^{+}\end{array}$ \\
\hline $\begin{array}{l}x 7700 \\
\times 7800\end{array}$ & $\begin{array}{l}\mathrm{F}^{-} \text {pro } A, \text { proB, lac, ø80dlac, ara, thi, malB, } \operatorname{Str}^{\mathrm{R}} \\
\mathrm{F}^{-} \text {proA, proB, lac, ø80dlac, ara, thi, malB, trpR, } \\
\text { Str }^{\mathrm{R}}\end{array}$ \\
\hline
\end{tabular}

Boezi \& DeMoss (196I)

Indole acrylic acid-resistant mutant of $\mathrm{T} 3$

Conjugation with $E$. coli KYI I 3

L. Baron

W. Reznikoff

W. Reznikoff

* Gene symbols: aroR and aroS denote mutations affecting transport of aromatic amino acids, glycine and alanine. The episome, $\mathrm{F}^{\prime}$ trp ${ }^{+}$cys $B^{+}$aro $R^{+}$tonB $B^{+}$coll ${ }^{+}, V^{+}, B^{+}$, is referred to as $\mathrm{F}^{\prime}$ trp. All other symbols are those recommended by Taylor \& Trotter (1972).

\section{Table 2. Salmonella typhimurium strains}

\begin{tabular}{|c|c|c|}
\hline Strain & Genetic loci* & Source \\
\hline LT2 & Wild type & P. Margolin \\
\hline supxi I & $\sup X-\operatorname{cys} B$ deletion & P. Margolin \\
\hline & supX, leu-500, ara9 & P. Margolin \\
\hline 2 & $\sup X$, leu-50o, ara 9 & P. Margolin \\
\hline OABEI 30 & trp $O A B E$ deletion & P. Margolin \\
\hline PM458 & $\operatorname{trp} A 512$ deletion, cysB529, leu-500 & P. Margolin \\
\hline PM566 & $\operatorname{trp} A B E D C I 67$ deletion, cys $B 529$, leu-500 & P. Margolin \\
\hline supx 33 & $\operatorname{trp} O A B$-sup $X$ deletion & Wuesthoff \& Bauerle (1970) \\
\hline BEDC107 & trpBEDC-chr-aroT deletion & Wuesthoff \& Bauerle (1970) \\
\hline ABEDCIOI & $\operatorname{trp} A B E D C$-chr-aroT deletion & Wuesthoff \& Bauerle (1970) \\
\hline BEDC43 & $\operatorname{trpBEDC}$ deletion & Wuesthoff \& Bauerle (1970) \\
\hline A49 & $\operatorname{trpA49}$ & Wuesthoff \& Bauerle (1970) \\
\hline A50 & trpAso & Wuesthoff \& Bauerle (1970) \\
\hline EI7I & $\operatorname{trpEI} \operatorname{ti}_{1}$ & Margolin \& Bauerle (I966) \\
\hline MTRI & 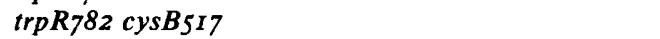 & Bauerle \& Margolin (1966) \\
\hline BEDC107/F'trp & $\begin{array}{l}\text { trpBEDC-chr-aroT deletion/ } \mathrm{F}^{\prime} \text { trp }{ }^{+} \text {cys } B^{+} \text {ton } B^{+} \\
\text {colI }^{+}, V^{+}, B^{+} \text {aroR } R^{+}\end{array}$ & $\begin{array}{l}\text { Conjugation with } E \text {. coll } \\
\text { KYII3 }\end{array}$ \\
\hline
\end{tabular}

* Gene symbols: aroT denotes the mutation affecting transport of aromatic amino acids, glycine and alanine. The episome $\mathrm{F}^{\prime} t r p^{+}, \operatorname{cysB}^{+}$, aro $\mathrm{R}^{+} \operatorname{tonB}^{+} \mathrm{coll}^{+}, \mathrm{V}^{+}, \mathrm{B}^{+}$, is referred to as $\mathrm{F}^{\prime} t r p$. All symbols are those recommended by Sanderson (1972). The strains from Margolin and his group are all derived from the wild type LT2.

mapped near the trp operon in both $E$. coli and $S$. typhimurium (Thorne \& Corwin, 1970). Subsequent studies have shown that the transport of phenylalanine and tyrosine, as well as alanine and glycine, is also lowered. The loci, which may or may not be homologous in the two genera, have been named aroT in $S$. typhimurium and aroR and $\operatorname{aroS}$ in $E$. coli. Their effect on aromatic amino acid transport is similar to aroP lesions (Ames, 1964; Brown, 1970). These studies were extended to include the role of tryptophan transport regulation by $\operatorname{trp} R$ (Thorne \& Corwin, 1971). This report describes the genetic mapping, regulation and kinetics of tryptophan transport by aroT strains of $S$. typhimurium and aro $R$ and aro $S$ strains of $E$. coli. 


\section{METHODS}

Bacteria. The Escherichia coli K12 and Salmonella typhimurium LT2 strains used are listed in Tables $I$ and 2 respectively. In comparing results for transport systems that are inducible or repressible, care was taken to delineate the strains used (preferably isogenic ones) and the growth conditions. Of the $E$. coli strains used, T3 and DBI are isogenic (DBI being an indole acrylic acid-resistant mutant of $\mathrm{T} 3$ ), and $\mathrm{X} 7700$ and $\times 7800 \mathrm{trpR}$ are isogenic $E$. coli KI2 strains. All the $S$. typhimurium strains received from P. Margolin were derived from LT2 and are well characterized (Table 2).

Phage. Virulent Pivir (PIvs) phage was obtained from L. Baron. Prvir lysates were prepared by a confluent lysis technique (Adams, 1959). Phage TI was prepared by the soft agar method described by Adams (1959). Phage P22 lysates were prepared according to the method of Margolin (1963)

Media. Rich medium was the LC broth of Luria \& Burrous (1957), Penassay broth or nutrient broth (Difco). The minimal medium (medium $\mathrm{A}$ ) was modified from Davis \& Mingioli (1950), and contained (g/l): $\mathrm{K}_{2} \mathrm{HPO}_{4}, 10 \cdot 5 ; \mathrm{KH}_{2} \mathrm{PO}_{4}, 4 \cdot 5 ;\left(\mathrm{NH}_{4}\right)_{2} \mathrm{SO}_{4}, \mathrm{I} \cdot 0 ; \mathrm{MgSO}_{4}$. ${ }_{7} \mathrm{H}_{2} \mathrm{O}, 0 \cdot \mathrm{I}$. When $2 \mathrm{~g}$ of glucose was added to this medium it was termed minimal glucose (MG) medium. Amino acids were added as required at $20 \mu \mathrm{g} / \mathrm{ml}$ unless otherwise noted. When derepression of transport was sought in tryptophan-requiring strains, $2 \mu \mathrm{g} /$ tryptophan $/ \mathrm{ml}$ rather than $20 \mu \mathrm{g} / \mathrm{ml}$ were added.

Genetic methods. Transductions with Prvir and P22 were carried out as described by Lennox (I955) and Margolin (1963), respectively. Sensitivity to phage TI was routinely tested by cross-streaking on LC agar. Mating experiments were done according to the method of Falkow et al. (1964).

Isolation of mutants resistant to indole acrylic acid. An $E$. coli culture of $\mathrm{T}_{3}$ grown overnight in Penassay broth was diluted I : 15 with fresh broth and allowed to grow to $\mathrm{I} \times 10^{7}$ cells $/ \mathrm{ml}$. A $5 \mathrm{ml}$ sample of the culture was centrifuged, washed twice and resuspended in $0.5 \mathrm{ml}$ of $0.1 \mathrm{M}$-sodium citrate buffer $\mathrm{pH} 5.0$. The cells were then treated with $N$-methyl- $N^{\prime}-$ nitro- $N$-nitrosoguanidine (NTG) according to the method of Adelberg, Mandel \& Chen (1965). The NTG-treated cells were spread on MG plates containing $100 \mu \mathrm{g}$ indole acrylic acid and I $\mu \mathrm{g}$ tryptophan $/ \mathrm{ml}$. The plates were incubated at $37^{\circ} \mathrm{C}$ for 3 to 4 days. Isolated colonies were picked, replica-plated on to fresh analogue-supplemented plates and assayed for tryptophan transporting ability. A representative strain DBI $(\operatorname{trp} E, \operatorname{tn} a A, \operatorname{aroS})$ was picked. This strain is not a rapid tryptophan excretor, because supernatant fluid from the mutant culture did not alter the extent of labelled tryptophan uptake by the parental strain T3. During isolation of the mutants the colonies were not surrounded by haloes of 'feeding' bacteria.

Ethidium bromide curing of $F^{\prime}$ trp episome. Cells harboring the $F^{\prime} t r p$ episome were grown overnight in nutrient broth and diluted to $10^{4} \mathrm{cells} / \mathrm{ml}$ in fresh nutrient broth $\mathrm{pH} 7.6$. Ethidium bromide was added to the diluted cells in a concentration range of 30 to $0.03 \mu \mathrm{g} / \mathrm{ml}$ (modification of the method of Bouanchaud, Scavizzi \& Chabbert, 1968). All cultures were allowed to grow overnight at $37^{\circ} \mathrm{C}$. Cultures with 60 to $80 \%$ of the growth of controls grown without ethidium bromide were replated on to nutrient agar plates. Isolated colonies were screened for Cys Trp phenotype by replicating on to single amino acid-supplemented MG plates.

Transport assay. Transport of amino acids was estimated as the amount of radioactivelylabelled compound accumulated by cells transferred to medium containing chloramphenicol. Under these conditions, the label was not incorporated to any appreciable extent into protein 
or other trichloroacetic acid-insoluble material, but was accumulated within the cell. This allows direct measurement of the initial rate of uptake. The growth medium contained sufficient glucose to inhibit the formation of tryptophanase by the $E$. coli strains which are tryptophanase positive (Freundlich \& Lichstein, 1960). Salmonella typhimurium LT2 and its derivatives do not utilize aromatic amino acids either as carbon or as nitrogen sources (Ames, 1964). Therefore, the uptake of radioactivity could be used as a measure of tryptophan transport unaffected by tryptophan metabolism.

The bacteria were grown overnight at $37^{\circ} \mathrm{C}$, with shaking, in MG medium supplemented with $20 \mu \mathrm{g} \mathrm{L}$-tryptophan/ml. Initially studies were performed using exponentially-growing cells; values obtained were in agreement with those using overnight ( 16 to $17 \mathrm{~h}$ ) cells. Derepression of the tryptophan transport system in salmonellae was achieved by omitting L-tryptophan or adding only $2 \mu \mathrm{g} / \mathrm{ml}$. Cells were harvested by centrifuging at $25^{\circ} \mathrm{C}$, washed and resuspended in medium A to a concentration of $\mathrm{I} \times 10^{9} \mathrm{cells} / \mathrm{ml}$. One $\mathrm{ml}$ of washed cells ( $1.5 \mathrm{mg}$ wet mass $/ \mathrm{ml}$ ) was then added to reaction mixture containing $12 \mu \mathrm{mol} \mathrm{MgCl}_{2}$, $15 \mu \mathrm{mol}$ tris- $\mathrm{HCl}$ buffer $\mathrm{pH} 8$, and $250 \mu \mathrm{g}$ chloramphenicol $/ \mathrm{ml}$, into a final volume of $7.0 \mathrm{ml}$. Radioactive amino acid was added at zero time and the mixture incubated at $25^{\circ} \mathrm{C}$. Samples ( $\mathrm{I} \mathrm{ml}$ ) were taken at $\mathrm{I} 5$ and $20 \mathrm{~s}$ and at $\mathrm{I}, 2,4$ and $6 \mathrm{~min}$, or as indicated, and filtered through membrane filters (Millipore type HA, $0.45 \mu \mathrm{m}$ pore size). The filtered cells were washed immediately with $5 \mathrm{ml}$ medium $\mathrm{A}\left(25^{\circ} \mathrm{C}\right)$, dried and counted in a butyl-PBDtoluene mixture ( $7 \mathrm{~g} \mathrm{PBD}$, from CIBA/1 toluene) in a Beckman-LS $200 \mathrm{~B}$ liquid scintillation counter. Controls were included in which $\mathrm{I} \mathrm{ml}$ of cells without radioactive amino acid was filtered, followed by $\mathrm{I} \mathrm{ml}$ of the same radioactive amino acid solution as that used in each transport assay. Filtering took $5 \mathrm{~s}$. The c.p.m. values in the controls, always less than the $15 \mathrm{~s}$ experimental values, were taken to represent the amino acid bound to the membrane filter and to the cells, and were subtracted from the experimental values. Data in this paper represent the mean values of three or more experiments, run on different days. The transport data are presented as either the initial rate of transport ( $30 \mathrm{~s}$ to I min) expressed as $\mu \mathrm{mol} / \mathrm{g}$ cells/min, or the $6 \mathrm{~min}$ accumulation level expressed as the concentration of the amino acid in cell water, based on the calculation of Broda (I968) that $10^{8}$ cells contain $1 \times 10^{-4} \mathrm{ml}$ of water. A ratio of the radioactivity concentration inside the cell $\left(G_{\text {in }}\right)$ to the radioactivity concentration outside the cell $\left(G_{\mathrm{ex}}\right)$ is presented to demonstrate the accumulation capabilities of the various strains after $6 \mathrm{~min}$ incubation.

Chemicals. Analytical reagent grade inorganic chemicals were used throughout. Organic chemicals were the highest grade commercially available. Radioactive amino acids obtained from New England Nuclear Corp., Boston, Massachusetts, U.S.A., included DL-[ $\left.{ }^{3} \mathrm{H}\right]$ tryptophan ( $185 \mathrm{mCi} / \mathrm{mmol})$, L- $\left[{ }^{3} \mathrm{H}\right]$ tryptophan $(33 \mathrm{mCi} / \mathrm{mmol}), \mathrm{L}-\left[{ }^{3} \mathrm{H}\right]$ tyrosine $(20 \mathrm{mCi} / \mathrm{mmol})$, L- $\left[{ }^{3} \mathrm{H}\right]$ phenylalanine $(135 \mathrm{mCi} / \mathrm{mmol}), \mathrm{L}-\left[{ }^{14} \mathrm{C}\right]$ leucine $(5000 \mathrm{mCi} / \mathrm{mmol}), \quad \mathrm{L}-\left[{ }^{14} \mathrm{C}\right]$ isoleucine (250 $\mathrm{mCi} / \mathrm{mmol}), \quad$ DL- $\left[{ }^{14} \mathrm{C}\right]$ lysine $(7 \cdot 1 \mathrm{mCi} / \mathrm{mmol}), \quad \mathrm{L}-\left[{ }^{14} \mathrm{C}\right]$ alanine (I $\mathrm{mCi} / \mathrm{mmol}$ ), and $\left[{ }^{14} \mathrm{C}\right]$ glycine $(4 \mathrm{mCi} / \mathrm{mmol})$. Indole acrylic acid was obtained from Sigma, NTG from Aldrich Chemical Co., New Jersey, U.S.A., scintillator butyl-PBD from CIBA Corp., Summit, New Jersey, and filters from Millipore. Ethidium bromide was generously given by Dr R. Herrmann.

\section{RESULTS}

Tryptophan uptake in E. coli $\mathrm{KI} 2$ and S. typhimurium LT2

Figure I illustrates the time course of tryptophan uptake by strains DBI. (an $E$. coli transport-deficient strain), its parental strain T3, the transport-deficient $S$. typhimurium BEDC107, and its parental strain LT2. In order to demonstrate optimal transport and 


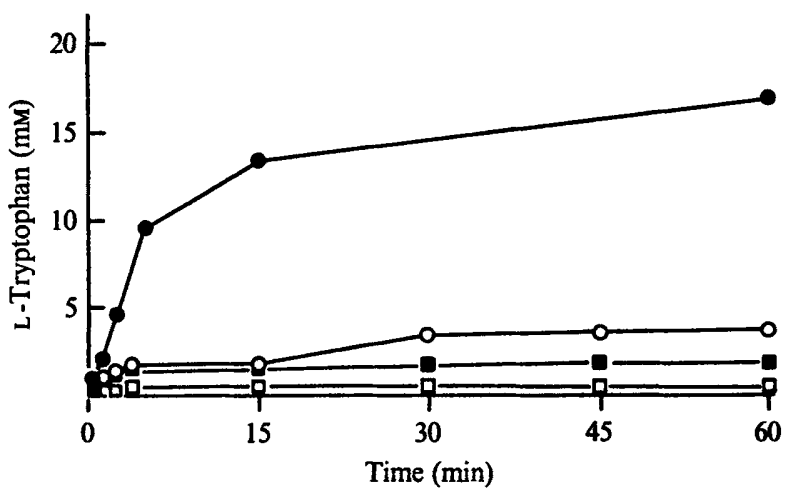

Fig. I. Time-course of tryptophan uptake in $E$. coli strains (O) T3 and (0) DBI, and $S$. typhimurium strains ( $\square$ ) LT2 and ( $\square$ ) BEDCI07. The $E$. coli strains were grown overnight in MG medium supplemented with $20 \mu \mathrm{g} / \mathrm{L}$-tryptophan $/ \mathrm{ml}$. The Salmonella strain LT2 was grown overnight in MG without L-tryptophan, and BEDCI07 was grown in MG medium supplemented with $2 \mu \mathrm{g}$ tryptophan/ ml. Cells were incubated with $\mathrm{L}-\left[{ }^{3} \mathrm{H}\right]$ tryptophan at a final concentration of $7 \cdot 1 \mu \mathrm{M}(33 \mathrm{mCi} / \mathrm{mmol})$ and uptake was expressed as the intracellular concentration of radioactive material.

\section{Table 3. Tryptophan uptake in E. coli and S. typhimurium. Comparison of apparent} Michaelis constants, maximum reaction velocities, and concentration ratios

Cells were grown overnight in MG medium with tryptophan supplementation at $20 \mu \mathrm{g} / \mathrm{ml}$ unless otherwise noted, i.e. (-) none, (2) $2 \mu \mathrm{g} / \mathrm{ml}$.

\begin{tabular}{|c|c|c|c|c|}
\hline & Genotype & $K_{\mathrm{m}} *(\mu \mathrm{M})$ & $(\mu \mathrm{moles} / \mathrm{g} \mathrm{cell} / \mathrm{min})$ & $G_{\text {in }} / G_{\text {ex }}^{\dagger}$ \\
\hline $\begin{array}{l}\text { E. coli } \\
\text { WI485 }\end{array}$ & Wild type & $I \cdot 4$ & $I \cdot 19$ & 6820 \\
\hline T3 & $\operatorname{trp} E$ (parent of DB-I) & $3 \cdot 0$ & I 29 & 5350 \\
\hline DBI & trpE aroS & I.4 & 0.35 & 2400 \\
\hline \multicolumn{5}{|c|}{ S. typhimurium } \\
\hline LT2 & Wild type & $\mathbf{I} \cdot \mathbf{3}$ & 0.50 & $\begin{array}{l}510 \\
1200(-)\end{array}$ \\
\hline BEDCIO7 & $\operatorname{trp} B E D C, c h r$, aroT & $1 \cdot 0$ & 0.08 & $\begin{array}{l}104 \\
225\end{array}$ \\
\hline
\end{tabular}

* $K_{\mathrm{m}}$ and $V_{\max }$ values were derived from Lineweaver-Burk plots of $(V)$ the initial rate of transport (30 s to I min) and (S) the ${ }^{3} \mathrm{H}-\mathrm{L}$-tryptophan concentrations over the range 0.43 to $19 \cdot 7 \mu \mathrm{M}$.

$\dagger$ Ratio of c.p.m. in bacterial cell water to initial concentration outside. $G_{\text {in }}$ is the c.p.m. accumulated during $6 \mathrm{~min}$ incubation; $G_{\text {ex }}$ is the initial external concentration of tryptophan (i.e. $0.43 \mu \mathrm{M} \mathrm{L}-\left[{ }^{3} \mathrm{H}\right]$ tryptophan).

accumulation by the two genera, the two $E$. coli strains were grown in media supplemented with L-tryptophan, while the two $S$. typhimurium strains were grown with $2 \mu \mathrm{g}$ tryptophan/ $\mathrm{ml}$ or no amino acid. The maximal rate of tryptophan uptake occurs from $30 \mathrm{~s}$ to I min, except in the $E$. coli parental strain T3 which maintains this rate for 4 to $6 \mathrm{~min}$. Under saturating conditions (i.e. radioactive substrate concentration $>2 \times K_{m}$ of transport for T3) a final level of accumulation was reached in $15 \mathrm{~min}$ by T3 and in $6 \mathrm{~min}$ by the other three strains. The plateau levels were maintained relatively constant for $\mathrm{I} h$.

\section{Saturation kinetics}

Lineweaver-Burk plots of the initial rate of uptake at varying L-tryptophan concentrations (a range of 0.43 to $19.7 \mu \mathrm{M}$ ) yielded Michaelis constants for these $E$. coli and $S$. $t y$ phimurium strains (Table 3). $G_{\mathrm{in}} / G_{\mathrm{ex}}$ ratios were also determined, to indicate the accumulation 


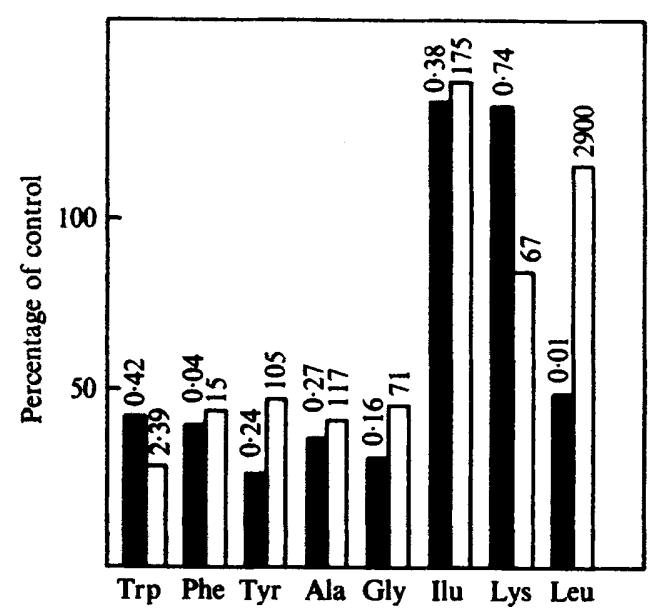

Fig. 2

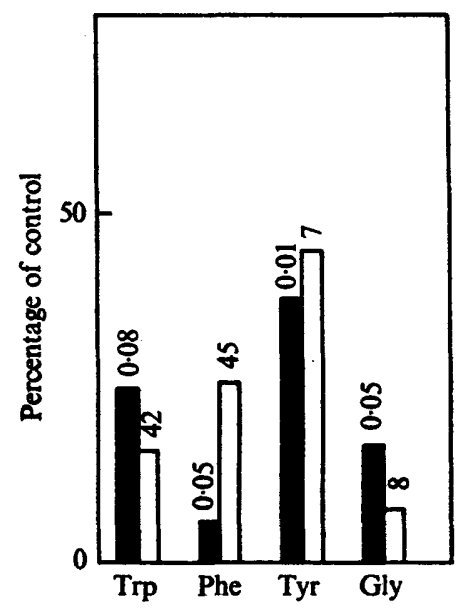

Fig. 3

Fig. 2. Transport of aliphatic, basic and aromatic amino acids by $E$. coli transport-deficient strain DBI. Data given are percentages relative to a value for the $E$. coli parental strain T3 of $100 \%$. The solid bars represent percentage initial rate of uptake $(\mu \mathrm{mol} / \mathrm{g}$ cells $/ \mathrm{min})$. The open bars represent percentage $G_{\text {in }} / G_{\text {ex }}$ ratio. Actual rate and ratio values for DBI appear at the bases of these bars. Both strains were grown overnight in MG medium supplemented with $20 \mu \mathrm{g} /$ tryptophan $/ \mathrm{ml}$. Symbols of radioactive amino acids used (and their specific activities) are: Ala, $\mathrm{L}-\left[{ }^{14} \mathrm{C}\right] \mathrm{lalanine}$ (II.5 $\mu \mathrm{M}$, II mCi/mmol); GLY, [ $\left[{ }^{4} \mathrm{Clglycine}\right.$ (II $5 \mu \mathrm{M}, 4 \mathrm{mCi} / \mathrm{mmol}$ ); Ile, $\mathrm{L}-\left[{ }^{14} \mathrm{C}\right]$ isoleucine (10.9 $\mu \mathrm{M}, 250 \mathrm{mCi} /$ mmol); Leu, L-[ $\left.{ }^{14} \mathrm{C}\right]$ leucine $(0.01 \mu \mathrm{M}, 5000 \mathrm{mCi} / \mathrm{mmol})$; Lys, DL- $\left[{ }^{44} \mathrm{C}\right]$ lysine $($ IO $\mu \mathrm{M}, 7 \cdot \mathrm{I} \mathrm{mCi} /$ mol); Phe, L-[ $\left.{ }^{3} \mathrm{H}\right]$ phenylalanine $(9 \cdot \mathrm{I} \mu \mathrm{M}, \mathrm{I} 35 \mathrm{mCi} / \mathrm{mmol}) ; \mathrm{Trp}, \mathrm{L}-\left[{ }^{3} \mathrm{H}\right] \operatorname{tryptophan}(7 \cdot \mathrm{I} \mu \mathrm{M}, 33 \mathrm{mCi} /$ mmol); Tyr, L-[ $\left.{ }^{3} \mathrm{H}\right]$ tyrosine $(7 \cdot 1 \mu \mathrm{M}, 20 \mathrm{mCi} / \mathrm{mmol})$.

Fig. 3. Transport of aromatic amino acids and glycine by $S$. typhimurium transport-deficient strain BEDC107. Data given are percentages relative to a value for the $S$. typhimurium parental strain LT2 of $100 \%$. The solid bars represent percentage initial rate of uptake $(\mu \mathrm{mol} / \mathrm{g}$ cells $/ \mathrm{min})$ while the open bars represent percentage $G_{\text {in }} / G_{\text {ex }}$ ratio. Actual rate and $G_{\text {in }} / G_{\text {ex }}$ values for BEDCI07 appear at the bases of these bars. Strain LT2 was grown overnight in MG medium without L-tryptophan, while BEDCIO7 was grown in MG medium supplemented with $2 \mu \mathrm{g}$ L-tryptophan $/ \mathrm{ml}$. For symbols of radioactive amino acids used and their specific activities, see Fig. 2.

ability of each strain. These ratios demonstrate the five-fold difference in accumulation ability of $E$. coli K12 wild type and $S$. typhimurium LT2. Mutation at the aroT or aroS regions results in an analogous loss of transport activity in both species. Escherichia coli DBI accumulated to a level $45 \%$ of that of its parent, T3. In $S$. typhimurium, the permease-deficient strain BEDC107 accumulated only $20 \%$ of that of wild-type LT2, regardless of the level of tryptophan in the growth medium.

$V_{\max }$ values were 4 to 6 times lower in the transport-deficient mutants, DBI and BEDCro7, while their apparent dissociation constants $\left(K_{m}\right)$ were in the same range as the parental wildtype strains of their respective genera.

\section{Uptake of aromatic and other amino acids by E. coli}

In the presence of a 20-fold excess of each of 17 amino acids, only phenylalanine and tyrosine interfered markedly with the uptake of $\mathrm{DL}-\left[{ }^{3} \mathrm{H}\right]$ tryptophan in $E$. coli $\mathrm{T} 3$ (Thorne, 1972). The aromatic amino acid uptake of DBI, the transport-deficient strain, and its parental strain $\mathrm{T} 3$ were compared using eight radioactively-labelled $\mathrm{L}$ or $\mathrm{DL}$ amino acids (Fig. 2). Strain DBI showed the greatest impairment in tryptophan transport of the amino acids tested, as reflected in a $G_{\text {in }} / G_{\text {ex }}$ ratio of $28 \%$ compared with control strain T3. The initial rates of transport and $G_{\mathrm{in}} / G_{\text {ex }}$ ratios as compared to control T3 were all below $50 \%$ for 


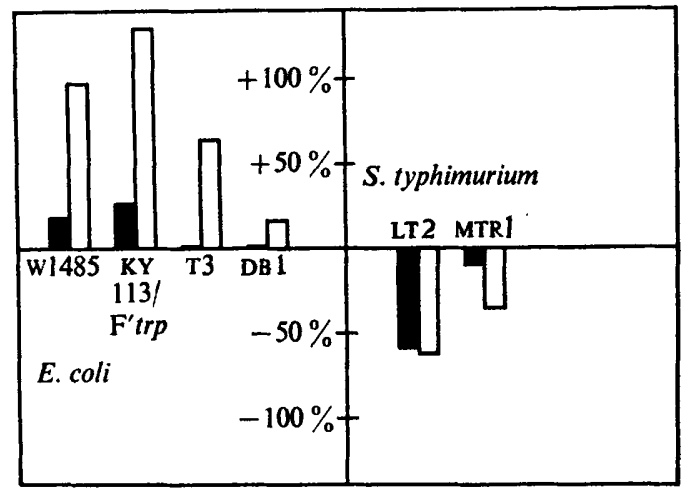

Fig. 4. Effect of growth in L-tryptophan-containing media on tryptophan transport. Cells grown overnight in MG medium alone, or MG medium supplemented with 2 or $20 \mu \mathrm{g}$ tryptophan $/ \mathrm{ml}$, were assayed as described in Methods using $L-\left[{ }^{3} \mathrm{H}\right]$ tryptophan $(7 \cdot 1 \mu \mathrm{M}, 33 \mathrm{mCi} / \mathrm{mmol})$. Initial rates and accumulation levels were calculated. The solid bars represent percentage change in initial rate ( $\mu \mathrm{mol} / \mathrm{g}$ cells $/ \mathrm{min}$ ) and the open bars represent percentage change in accumulation $(\mu \mathrm{mol} / \mathrm{g}$ cells). Escherichia coli data given are percentages relative to a value for $E$. coli $\mathrm{kI} 2$ wI 485 of $100 \%$ (initial rate when grown without tryptophan was I.I I $\mu \mathrm{mol} / \mathrm{g}$ cells/min, accumulation was 3.60 $\mu \mathrm{mol} / \mathrm{g})$. Salmonella typhimurium data given are percentages relative to a value for $S$. typhimurium LT 2 of $100 \%$ (initial rate when grown without tryptophan was $0.39 \mu \mathrm{mol} / \mathrm{g}$ cells $/ \mathrm{min}$, accumulation was $\mathrm{I} \cdot 3 \mathrm{I} \mu \mathrm{mol} / \mathrm{g}$ cells).

phenylalanine, tyrosine, alanine and glycine. The initial rates and $G_{\mathrm{In}} / G_{\mathrm{ex}}$ ratio of $\mathrm{DBI}$ for isoleucine and lysine were similar to the parental strain T3. Although a low concentration of leucine was used in these assays (0.0I $\mu \mathrm{M}$ ), the low initial rate for leucine uptake by DBI was consistently found. The $G_{\mathrm{ta}} / G_{\mathrm{ex}}$ ratio for leucine uptake of DBI, however, appears similar to parental T3.

\section{Uptake of aromatic and other amino acids by S. typhimurium}

In S. typhimurium, the transport defects of strain BEDCI07.were examined (Fig. 3). Comparison of strain BEDCI07 with wild-type LT2 revealed defects in transport of the aromatic amino acids and glycine. Rates and accumulation ratios, expressed as percentages of those of the control strain LT2, were all well below $50 \%$.

Study of leucine transport by various trp-chr deletion strains of $S$. typhimurium revealed the presence of a locus affecting leucine transport on the side of the chr marker distal to the trp operon (Thorne \& Corwin, 1972). This locus is thought not to be involved in aromatic amino acid transport. L- $\left[{ }^{4} \mathrm{C}\right]$ alanine transport assays showed this amino acid to be poorly transported in all Salmonella strains tested compared with $E$. coli (Thorne, 1972).

\section{Regulation of aromatic transport in E. coli}

In $E$. coli the aromatic permease is not controlled by the tryptophan regulator gene, since the presence or absence of the $\operatorname{trp} R$ gene has no effect on permease regulation. This was shown by the identical uptake of DL- $\left[{ }^{3} \mathrm{H}\right]$ tryptophan by the two isogenic $E$. coli KI2 strains $\mathrm{x} 7700$ and $\mathrm{x} 7800$, which differ only by a $\operatorname{trp} \boldsymbol{R}$ mutation. Maximal rates of uptake after growth in the presence of $20 \mu \mathrm{g}$ tryptophan $/ \mathrm{ml}$ were 0.34 and $0.36 \mu \mathrm{mol} / \mathrm{g}$ cells $/ \mathrm{min}$, while the accumulations inside the cells after $6 \mathrm{~min}$ incubation were $\mathrm{I} \cdot 63$ and $\mathrm{I} \cdot 72 \mu \mathrm{mol} / \mathrm{g}$ cells respectively. Thus the $\operatorname{trp} R$ gene does not play a role in the regulation of tryptophan transport. 

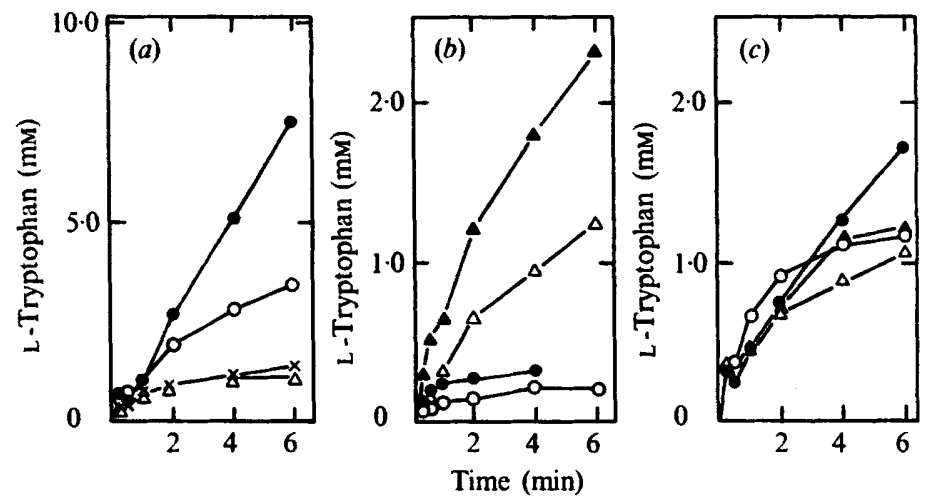

Fig. 5. Effect of $E$. coli $F^{\prime}$ trp episome on tryptophan uptake by various $E$. coli and $S$. typhimurium strains. (a) $\mathrm{L}-\left[{ }^{3} \mathrm{H}\right]$ tryptophan $(7 \cdot 1 \mu \mathrm{M}, 33 \mathrm{mCi} / \mathrm{mmol})$ uptake (expressed as the intracellular concentration of radioactive material) into: $O, E$. coli $\mathrm{KYII} / \mathrm{F}^{\prime} \operatorname{trp}$ grown overnight in $\mathrm{MG}+20 \mu \mathrm{g} \mathrm{L}$ tryptophan/ml; O, E. coli $\mathrm{KYII} / 3 / \mathrm{F}^{\prime}$ trp grown overnight in $\mathrm{MG} ; \times, \mathrm{KYII} 3$ (cured) grown overnight in MG $+20 \mu \mathrm{g}$ L-tryptophan $/ \mathrm{ml} ; \triangle$, KYII3 (cured) grown overnight in MG medium + $2 \mu \mathrm{g}$ L-tryptophan and $20 \mu \mathrm{g}$ cysteine/ml. (b) $\mathrm{L}-\left[{ }^{3} \mathrm{H}\right]$ tryptophan $(7 \cdot \mathrm{I} \mu \mathrm{M}, 33 \mathrm{mCi} / \mathrm{mmol})$ uptake (expressed as the intracellular concentration of radioactive material) into: $\mathbf{\Lambda}$, Salmonella hybrid BEDC107/F'trp grown overnight in MG medium; $\triangle$, BEDC107/F'trp grown overnight in MG medium $+20 \mu \mathrm{g} \mathrm{L}$-tryptophan $/ \mathrm{ml} ; \mathbf{O}$, BEDC107 grown in $\mathbf{M G}+2 \mu \mathrm{g}$ L-tryptophan $/ \mathrm{ml} ; 0$, BEDCIO7 grown in $\mathrm{MG}+20 \mu \mathrm{g}$ L-tryptophan $/ \mathrm{ml}$. (c) $\mathrm{L}-\left[{ }^{3} \mathrm{H}\right]$-tryptophan $(7 \cdot \mathrm{I} \mu \mathrm{M}, 33 \mathrm{mCi} / \mathrm{mmol})$ uptake (expressed as the intracellular concentration of radioactive material) into:,$E$. coli DBI grown overnight in MG $+20 \mu \mathrm{g}$ L-tryptophan $/ \mathrm{ml} ; \mathrm{O}, \mathrm{DBI}$ grown overnight in MG $+2 \mu \mathrm{g}$ L-tryptophan $/ \mathrm{ml}$; $\triangle, \mathrm{DBI} / \mathrm{F}^{\prime}$ trp grown overnight in $\mathrm{MG} ;(\triangle) \mathrm{DBI} / \mathrm{F}^{\prime}$ trp grown overnight in MG $+20 \mu \mathrm{g}$ L-tryptophan/ $\mathrm{ml}$.

Following growth with tryptophan, $E$. coli strains KYI I $3 / F^{\prime} t r p$ and WI 485 showed $50 \%$ increases and $\mathrm{T} 3$ a $33 \%$ increase in the amounts of tryptophan accumulated after $6 \mathrm{~min}$ incubation (Fig. 4). The initial uptake rates were only slightly affected by growth on tryptophan, thus appearing constitutive. These results suggest that tryptophan accumulation can be increased by growth in the presence of this amino acid.

\section{Regulation of aromatic transport in $S$. typhimurium}

Transport by the wild-type $S$. typhimurium LT2 was regulated by prior growth in the presence of tryptophan (Fig. 4). Repression of tryptophan uptake resulted after growth in tryptophan-supplemented media. The accumulation of tryptophan by the $\operatorname{trp} R$ strain MTR I was still significantly repressed and therefore regulated by tryptophan. Thus, as in $E$. coli, the trp operon regulator system of $S$. typhimurium does not appear to control tryptophan uptake.

\section{Mapping of the aroR, aroS and aroT loci affecting aromatic amino acid uptake in $E$. coli and $S$. typhimurium}

Escherichia coli strain KYI I 3 contains a very large chromosomal deletion of the cysB-trp$\operatorname{ton} B$ region. This genetic lesion is compensated for in this cell by the presence of the episome $\mathrm{F}^{\prime}$ coll, $V, B^{+}$cys $B^{+} \operatorname{trp}{ }^{+} \operatorname{ton} B^{+}$(referred to below as $\mathrm{F}^{\prime}$ trp) which covers the genetic gap on the chromosome. Ethidium bromide removal of the episome results in an endogenote with a deletion extending through the trp operon and neighbouring ton $B$ and $c y s B$ regions. Curing of the episome was assessed easily, since these strains upon curing regained a requirement for cysteine and tryptophan, and became resistant to phage $T_{I}$ and indole acrylic acid (IA), 


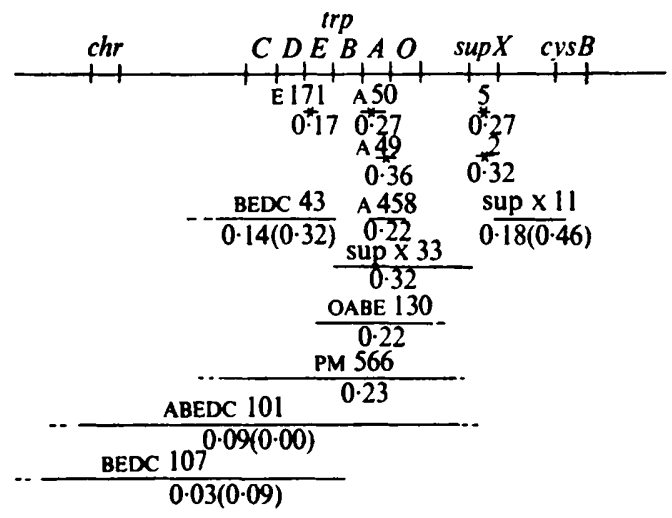

Fig. 6. The chr-trp-supX-cysB portion of the $S$. typhimurium chromosome. The lines below the chromosome represent the approximate extent of the deletions in the mutant strains listed above the line except where an $\times$ through the line denotes a point mutation. Below the line are the initial rates of L-tryptophan uptake of each strain, expressed as $\mu \mathrm{mol} / \mathrm{g}$ cells/min (30 s to I min values). The rates in parentheses are for cells grown overnight in MG medium supplemented with $2 \mu \mathrm{g}$ L-tryptophan $/ \mathrm{ml}$; otherwise, cells were grown in media with $20 \mu \mathrm{g}$ tryptophan $/ \mathrm{ml}$. Assays were performed with $L-\left[{ }^{2} \mathrm{H}\right]$ tryptophan at a final concentration of $7 \cdot 1 \mu_{\mathrm{M}}(33 \mathrm{mCi} / \mathrm{mmol})$. Each value is the average of two or more experiments run on separate days. Symbols: chr, chromium ion sensitivity; trp, tryptophan operon; sup $X$, suppressor of leucine-500 operator mutation; cys $B$, cysteine regulation.

the latter suggesting that the gene for aromatic amino acid uptake might lie within the chromosomal deletion.

Transport of tryptophan in KYII3 before and after curing provided the first clue to the location of aroR (Fig. 5a). After curing the strain of the $F^{\prime} t r p$ episome, the amount of tryptophan transported by the cells was reduced by $80 \%$ compared with the hybrid. The initial rate of uptake and intracellular level after $6 \mathrm{~min}$ in the cured strain were the same whether the cells had been grown with 2 or $20 \mu \mathrm{g}$ tryptophan $/ \mathrm{ml}$. Thus the decrease in rate of uptake and accumulation in the cured strains is not the result of repression of transport by growth in tryptophan, but is due to the alteration of a component required for tryptophan transport that is coded for by a gene on the $\mathrm{F}^{\prime}$ trp episome. This gene has been termed aroR.

To determine the location of the aroR gene of $E$. coli more precisely we made use of various deletion mutants of $S$. typhimurium LT2 that had been isolated and identified by Margolin and his group (Table 2). This is a feasible approach because the genetic map in $S$. typhimurium is analogous to that of $E$. coli in the region of the trp operon. The five genes of the trp operon are aligned in the same sequence in both genera. Although the operons show opposite orientation with respect to other chromosomal markers, the relationship of the trp operon to closely linked genes is identical in the two genera (Sanderson, 1972; Taylor \& Trotter, 1972). The E. coli tonB locus is also analogous to the chr locus in S. typhimurium since ton $B$ point mutants WD38 and 169 are also sensitive to chromium ion (Thorne, 1972).

The genetic map of the Salmonella strains studied is shown in Fig. 6 together with the initial rates of $\mathrm{L}-\left[{ }^{3} \mathrm{H}\right]$ tryptophan uptake in these strains. The various strains with point mutations and deletions which cover the $\operatorname{trp}$ operon and extend through $\sup X$ and $\operatorname{cys} B$ all have initial rates of tryptophan uptake which are similar to that of wild-type LT2 $(0.32 \mu \mathrm{mol} /$ $\mathrm{g}$ cells/min). The lowest initial rates of transport were exhibited by BEDCIO7 and ABEDCIOI, even under derepressed conditions (growth in $2 \mu \mathrm{g}$ tryptophan/ml). Both ABEDCIOI and 
BEDC107 carry deletions extending through the chr locus (Corwin et al. 1966). These results suggest that a locus exists, on the chr side of the $\operatorname{trp}$ operon, which is involved in aromatic amino acid transport; we have termed this gene aroT.

To determine the location of the aroT region in relation to the $c h r$ (chromium ion sensi tivity) and trp loci, strain BEDCI07 (trpBEDC, chr, aroT) was transduced to chromium resistance $\left(\mathrm{Chr}^{\mathrm{R}}\right)$ with a $\mathbf{P}_{22}$ lysate from wild-type strain $\mathbf{L T 2}$. $\mathrm{Chr}^{\mathrm{R}}$ transductants were tested for tryptophan requirement and rate of uptake of this amino acid. All $20 \mathrm{Chr}^{\mathrm{R}} \mathrm{Trp}^{+}$ transductants tested were able to take up tryptophan at rates identical to wild type, LT2. $\mathrm{Chr}^{\mathrm{R}} \mathrm{Trp}^{-}$transductants were also found, indicating that either the recipient strain actually possesses a double deletion or that partial diploids were formed. Nineteen of the $20 \mathrm{Chr}^{\mathbf{R}}$ Trp- transductants tested retained low transport ability. This result, coupled with the normal rate of uptake of the various chr-trp-sup $X$-cysB deletion strains (Fig. 6), suggest that in $S$. typhimurium the aroT region lies between $c h r$ and the trp operon. However, as the transduction data cannot be interpreted with certainty, the exact location of aro $T$ remains unknown.

The results of the following intergeneric mating give added evidence for the presence of a gene coding for a transport component in the $\mathrm{F}^{\prime}$ trp episome. The BEDCIO7 strain of S. typhimurium has a low derepressed rate of transport and low steady-state accumulation of tryptophan when grown on $2 \mu \mathrm{g}$ tryptophan/ml. After conjugation with $E$. coli cells harbouring the $\mathrm{F}^{\prime}$ trp episome, the $S$. typhimurium $\mathrm{F}^{\prime}$ trp hybrid had increased transport ability (Fig. $5 b$ ). This suggests that the $E$. coli aroR gene is homologous with the $S$. typhimurium aroT gene. As mentioned previously, in $S$. typhimurium transport was repressed by prior growth in MG-tryptophan medium. This regulation exerted control over the expression of the $E$. coli $\mathrm{F}^{\prime}$ trp aroR gene, because prior growth in MG-tryptophan medium caused repression of both the transport rate and accumulation level. Even under derepressed conditions (no tryptophan supplement) the $S$. typhimurium $F^{\prime}$ trp hybrid had a transport rate and an accumulation level which was considerably below the normal $E$. coli range (note the difference in scale between Fig. $5 a$ and Fig. $5 b$ and $c$ ). This result may indicate the presence of a tryptophan transport regulator gene in $S$. typhimurium which causes repression of transport after prior growth in tryptophan, and controls the expression of the $E$. coli episomal genetic message.

The results of the intra-generic mating are more difficult to interpret (Fig. $5 c$ ). When $F^{\prime}$ trp was transferred into DBI, the early transport rates were changed very little. It seems very likely therefore that the genetic lesion (aroT) in $S$. typhimurium BEDCIO7 and the probably homologous region aroR in the cured $E$. coli KYII3, which are correctable by the $F^{\prime} t r p$ episome, are different from the lesion $(a r o S)$ in $E$. coli DBI which is not so correctable. Thus the genetic lesion in DBI must lie outside the range of DNA covered by the $F^{\prime}$ trp episome.

Evidence that the mutational locus in $E$. coli DBI lies near the trp operon was supplied by PI transduction. The indole acrylic acid (IA)-resistant strain DBI (trpE, tnaA, aroS) was transduced to Trp ${ }^{+}$with a PI lysate from the wild-type $E$. coli KI 2 strain WI485. Of the 57 $\mathrm{Trp}^{+}$transductants tested, 22 were IA sensitive. Therefore the frequency of co-transduction of IA sensitivity with tryptophan requirement was $38 \%$. The exact location of DBI relative to the trp region in E. coli remains to be determined, for although aroS is co-transducible with $\operatorname{tr} p$ it lies outside the region contained in $\mathrm{F}^{\prime} t r p$.

The possibility that the uptake-deficiency of E. coli DBI and/or S. typhimurium BEDCIO7 is due to a cell wall defect caused by a mutation involving galU (linked to $\operatorname{trp}$ ) can be ruled out, since these strains are galactose positive and in addition DBI can absorb phage $P_{I}$; 
neither of these characters can be shown by galU mutants (Shapiro, 1966; Rapin \& Kalckar, 1971).

\section{DISCUSSION}

This study presents evidence that general aromatic amino acid transport and uptake of glycine and alanine is impaired in aroR, aro $S$ and aroT strains of $E$. coli and $S$. typhimurium, respectively, caused by genetic lesions near the $\operatorname{trp}$ operon and the tonB or $\operatorname{chr}$ loci. The transport defects displayed by these mutations are similar to the aroP mutations in $E$. coli (Brown, 1970) and S. typhimurium (Ames, 1964). In E. coli, mutation in aroP results in roughly a $75 \%$ decrease in transport of labelled aromatic amino acids by whole cells. Inhibition studies indicate that in $E$. coli, the general aromatic transport system aroP has a high affinity for phenylalanine, tyrosine and tryptophan and lower affinity for cysteine, leucine, alanine, methionine, histidine and aspartic acid.

In our study, aromatic amino acid transport by aroT, aro $R$, aro $S$ strains appears similar to that of aroP. Of the other neutral and basic amino acids which were directly tested, uptake of alanine and glycine were also impaired.

Both the cured $E$. coli KYII3 and $S$. typhimurium BEDCI07 deletions termed aroR and aroT respectively have their tryptophan transport and IA phenotype restored to normal by the presence of the $F^{\prime} t r p$ episome. Transduction studies and rates of uptake of various chr-trp-sup $X$-cys $B$ deletion strains suggests that the transport defect of $S$. typhimurium aroT strain BEDCIO 7 is located between trp and chr. Thus the aroT and aroR mutation can be located on the tonB or $c h r$ side of the $\operatorname{trp}$ operon, and results in impaired transport of labelled aromatic amino acids in $E$. coli $\mathrm{K} 12$ and $S$. typhimurium. The IA ${ }^{\mathrm{R}}$ character of $E$. coli strain DBI $(a r o S)$ is co-transduced with trp, and if the transport defect of DBI (which is similar to the cured $\mathrm{IA}^{\mathrm{R}}$ KYII3 deletion strain) is directly related to its IA resistance, then the genetic locus aroS is also close to the trp operon although outside the region contained in $F^{\prime}$ trp. Exact correlation of the resistance phenotype with the transport defect was not made. The possibility remains of DBI being a double mutant, especially since it was produced by NTG mutagenesis (Guerola, Ingraham \& Cerdá-Olmedo, 1971). Location of the aroT, aroR and possibly aroS regions near the trp operon raises the question of whether there are two or more genetic loci coding for separate components functioning in general aromatic amino acid transport. This may be so, since the aroP mutations and the aro $S$ mutation were isolated on the basis of resistance to three different analogues.

The similarities in $K_{m}$ of wild-type and aroT and aroS strains suggest that the mutations do not alter the structure of a binding protein involved in transport. The decrease in the $V_{\max }$ of DBI (aroS) and BEDCI07 (aroT) may be associated with loss of transport components or with alterations in the cell wall around the transport components which cause the transport reactions to proceed more slowly. Binding proteins may play a role in aromatic amino acid transport. Guroff \& Bromwell (1970) have reported the isolation of a phenylalaninebinding protein from Comamonas sp. Such structural defects may lead to loss of transport components from the periplasmic space due to an incomplete cell wall, thereby contributing to a smaller number of transport proteins capable of reacting with the substrate.

A preliminary study of $S$. typhimurium strains possessing different defects in their lipopolysaccharide structure (SLI I 81, SL896, SLI 197, SLI034, HN300 and HN308; see Gemski \& Stocker, 1967; Nakae \& Nikaido, 1971) indicated that strains with $r f b T$, rfaL and galU mutations had 14 to $38 \%$ lower initial rates and accumulation levels of tryptophan uptake than the wild-type LT2 (Thorne, 1972). While only the tryptophan transport ability of these rough strains was assayed, one might suspect that such lipopolysaccharide defects may have 
a generalized effect involving other transport systems as well. It may be noted that DBI transports glycine and alanine poorly and BEDCIO7 has a deficient glycine uptake. The presence of galU mutations was ruled out in both strains, although other cell-wall defects cannot be precluded.

Other studies have shown that the area around the $\operatorname{trp}$-tonB loci in $E$. coli contains genes for a number of bacterial cell-surface components. Mutations in these regions lead to deficiencies in transport of iron (Cox et al., 1970; Wang \& Newton, 1969 $a, b, 1971$ ) and resistance to phages $\mathrm{TI}_{\mathrm{I}}, \phi 80$ and colicins B, I, and V (Gratia, 1966; Signer, I966; Yanofsky \& Lennox, 1959). Our mapping data have revealed regions in both $E$. coli and $S$. typhimurium in this same area concerned with the ability to transport the aromatic amino acids, glycine, and alanine. There is also evidence of a different region affecting leucine transport ability on the side of the chr locus distal to the trp operon (Thorne \& Corwin, 1972).

An example of a mutation with a missing surface component associated with a pleiotropic transport effect has been demonstrated in ctr strains of $E$. coli (Wang, Morse \& Morse, 1969; Dahl, Wang \& Morse, 197I). These are defective in the uptake of various carbohydrates and of tryptophan, and are located $20 \mathrm{~min}$ from the $\operatorname{trp}$-ton $B$ area. The $c t r$ mutational effect on tryptophan uptake was confined to the specific inducible transport system for tryptophan.

Comparison of tryptophan transport by E. coli and S. typhimurium. The ability to transport tryptophan is lower in wild-type $S$. typhimurium than in wild-type $E$. coli KI2, even under conditions of maximal transport activity. Either the salmonella normally contain a mechanism responsible for maintaining a relatively low level of tryptophan transport by regulating the number of transport carriers, or perhaps differences in the cell envelope of the salmonellae are sufficient to provide more of a physical barrier to passage of amino acids (Robbie \& Wilson, 1969), or there could be a different amount of metabolic energy made available for active transport. Significantly, the capacity for tryptophan transport in $S$. typhimurium harbouring the F'trp episome from $E$. coli never achieved levels found in $E$. coli harbouring the episome, but remained at the lower level of wild-type salmonellae.

Comparison of regulation of tryptophan transport and trp operon. Somerville (1966) reported the regulation of expression of episomal $E$. coli tryptophan biosynthetic enzymes in strains of $S$. typhimurium whose chromosomes were deleted through the trp operon. The response to regulation in the $S$. typhimurium $\mathrm{F}^{\prime}$ trp hybrid was the same as that in the $E$. coli wild type. Thus, although regulation of trp operon structural genes is similar in the two genera, this is not the case with the aromatic transport system. Our findings indicate that the $\operatorname{trp} R$ locus, which regulates the $\operatorname{tr} p$ structural genes, appears to have no effect on tryptophan transport in $E$. coli and $S$. typhimurium. The two genera differ in their response to L-tryptophan supplementation. In $E$. coli, accumulation of tryptophan is normally enhanced by growth in tryptophan, while in $S$. typhimurium, accumulation is depressed by such growth conditions.

We thank Drs S. A. Broitman, E. Kashket and P. Gemski for invaluable assistance during the course of this work and preparation of the manuscript, and Dr P. Margolin for his guidance in selection of strains as well as for donating them. We also thank Drs W. Renzikoff, B. A. D. Stocker and H. Nikaido for supplying stock strains, and Mrs Irene Burr for incredible patience and excellent secretarial assistance. G.M.T. was supported by a predoctoral fellowship from the National Aeronautics and Space Administration. 


\section{REFERENCES}

ADAms, M. H. (1959). Bacteriophages, pp. 454-460. New York: Interscience Publishers.

Adelberg, E. A., MANDel, M. \& Chen, G. C. C. (1965). Optimal conditions for mutagenesis by $N$-methyl- $N^{\prime}$ nitro- $N$-nitrosoguanadine in Escherichia coli $\mathrm{KI}$ 2. Biochemical and Biophysical Research Communications I8, 788-795.

Ames, G. F. (1964). Uptake of amino acids by Salmonella typhimurium. Archives of Biochemistry and Biophysics 104, 1-18.

AMES, G. F. \& RотH, J. R. (I968). Histidine and aromatic permeases of Salmonella typhimurium. Journal of Bacteriology 96, I742-I 749.

Bauerle, R. H. \& Margolin, P. (1966). The functional organization of the tryptophan gene cluster in Salmonella typhimurium. Proceedings of the National Academy of Sciences of the United States of America 56, I I I-I I8.

Boezi, J. A. \& DeMoss, R. D. (1961). Properties of a tryptophan transport system in Escherichia coli. Biochimica et biophysica acta 49, 471-484.

Bouanchaud, D. H., Scavizzi, M. R. \& Chabbert, Y. A. (1968). Elimination by ethidium bromide of antibiotic resistance in Enterobacteria and Staphylococci. Journal of General Microbiology 54, 4I 7-425.

Broda, P. (1968). Ribonucleic acid synthesis and glutamate excretion in Escherichia coli. Journal of Bacterio$\log y$ 96, 1528-I 534 .

Brown, K. D. (1970). Formation of aromatic amino acid pools in Escherichia coli K-12. Journal of Bacteriology 104, 177-188.

Corwin, L. M., Fanning, G. R., Feldman, F. \& Margclin, P. (1966). Mutation leading to increased sensitivity to chromium in Salmonella typhimurium. Journal of Bacteriology 9r, I509-15I5.

Cox, G. B., Gibson, F., Luke, R. K. J., Newton, N. A., O’Brien, I. G. \& Rosenberg, H. (1970). Mutations affecting iron transport in Escherichia coli. Journal of Bacteriology 104, 219-226.

DAHL, R., WANG, R. J. \& MORSE, M. L. (197I). Effect of pleiotropic carbohydrate mutations (ctr) on tryptophan catabolism. Journal of Bacteriology 107, 513-518.

DAvis, B. D. \& Mingroli, E. S. (1950). Mutants of Escherichia coli requiring methionine or vitamin B-I 2. Journal of Bacteriology 60, 17-28.

Falkow, S., Wohlhieter, J. A., Citarella, R. V. \& Baron, L. S. (1964). Transfer of episomic elements to Proteus. I. Transfer of F-linked chromosomal determinants. Journal of Bacteriology 87, $209-219$.

Freundich, M. \& LichsteIn, H. C. (1960). Inhibitory effect of glucose on tryptophanase. Journal of Bacteriology 80, 633-638.

Gemski, P., JUN. \& StockeR, B. A. D. (1967). Transduction by bacteriophage P22 in nonsmooth mutants of Salmonella typhimurium. Journal of Bacteriology 93, 1588-1 597.

Gratia, J. P. (1966). Studies on defective lysogeny due to chromosomal deletion in Escherichia coli. I. Single lysogens. Biken Journal 9, 77-87.

Guerola, N., INGRAhaM, J. L. \& CerdÁ-Olmedo, E. (1971). Induction of closely linked multiple mutations by nitrosoguanidine. Nature New Biology 230, $122-125$.

GUEST, J. R. (I 974). Gene-protein relationships of the $\alpha$-keto acid dehydrogenase complexes of Escherichia coli K12: chromosomal location of the lipoamide dehydrogenase gene. Journal of General Microbiology 80, 523-532.

Guroff, G. \& Bromwell, K. E. (I970). Phenylalanine uptake and phenylalanine-binding material in Comamonas sp. (ATCCI 1299a). Archives of Biochemistry and Biophysics 137, 379-387.

LANGLEY, D. \& GuesT, J. R. (1974). Biochemical and genetic characteristics of deletion and other mutant strains of Salmonella typhimurium LT2 lacking $\alpha$-keto acid dehydrogenase complex activities. Journal of General Microbiology 82, 319-335.

Lennox, E. S. (1955). Transduction of linked genetic characters of the host by bacteriophage PI. Virology I, 190-206.

LURIA, S. E. \& BURRous, J. W. (1957). Hybridization between Escherichia coli and Shigella. Journal of Bacteriology 74, 46I-476.

Margolin, P. (1963). Genetic fine structure of the leucine operon in Salmonella. Genetics 48, $441-457$.

Margolin, P. \& BaUerle, R. H. (1966). Determinants for regulation and initiation of expression of tryptophan genes. Cold Spring Harbor Symposia on Quantitative Biology 3r, 31 I-320.

NAKAE, T. \& NikaIDo, H. (I97I). Multiple molecular forms of uridine diphosphate glucose pyrophosphorylase from Salmonella typhimurium. II. Genetic determination of multiple forms. Journal of Biological Chemistry 246, 4397-4403. 
PIPERno, J. R. \& OXENDER, D. L. (1968). Amino acid transport systems in Escherichia coli K-I 2. Journal of Biological Chemistry 243, 5914-5920.

RAPIN, A. M. C. \& KalCKAR, H. M. (197I). The relation of bacteriophage attachment to lipopolysaccharide structure. In Microbiology. Toxins IV, p. 293. Edited by G. Weinbaum, S. Kadis and S. Ajl. New York: Academic Press.

RoBBIE, J. P. \& WILSON, T. H. (1969). Transmembrane effects of $\beta$-galactosides on thiomethyl- $\beta$-galactoside transport in Escherichia coli. Biochimica et biophysica acta 173, 234-244.

SANDERSON, K. E. (1972). Linkage map of Salmonella typhimurium. Edition IV. Bacteriological Reviews 36, $558-586$.

ShAPIRo, J. A. (1966). Chromosomal location of the gene determining uridine diphosphoglucose formation in Escherichia coli K-12. Journal of Bacteriology 92, 518-520.

SIGNER, E. R. (1966). Interaction of prophages at the att ${ }_{\mathbf{8 0}}$ site with the chromosome of Escherichia coli. Journal of Molecular Biology 15, 243-255.

SOMERVILLE, R. L. (1966). Tryptophan operon of Escherichia coli: regulatory behavior in Salmonella typhimurium cytoplasm. Science, New York 154, 1585-1587.

TAYLOR, A. L. \& TrotTER, C. D. (1972). Linkage map of Escherichia coli strain K-12. Bacteriological Reviews 36, 504-524.

ThoRNe, G. M. (1972). Tryptophan transport in the Enterobactereaceae. Ph.D. thesis, Boston University.

THORNE, G. M. \& CoRwIN, L. M. (1970). Mapping of tryptophan permease gene in Escherichia coli and Salmonella typhimurium. Bacteriological Proceedings 70, 2 I.

ThorNe, G. M. \& Corwin, L. M. (I97I). Regulation of tryptophan permease levels in Enterobacteriaceae. Federation Proceedings 30, III 5.

ThORNE, G. M. \& CoRwin, L. M. (1972). Genetic locus of a gene affecting leucine transport in Salmonella typhimurium. Journal of Bacteriology 110, 784-785.

WANG, C. C. \& Newton, A. (1969a). Iron transport in Escherichia coli: relationship between chromium sensitivity and high iron requirement in mutants of Escherichia coli. Journal of Bacteriology 98, II 35114 I.

WANG, C. C. \& Newron, A. (1969b). Iron transport in Escherichia coli: roles of energy-dependent uptake and 2,3-dihydroxybenzoylserine. Journal of Bacteriology 98, I $142-1$ I 50.

WANG, C. C. \& NewTon, A. (1971). An additional step in the transport of iron defined by the ton $B$ locus of Escherichia coli. Journal of Biological Chemistry 246, $2147-2151$.

WANG, R. J., MORSE, H. G. \& MORSE, M. L. (1969). Carbohydrate accumulation and metabolism in Escherichia coli: the close linkage and chromosomal location of ctr mutations. Journal of Bacteriology 98, 605-610.

WUESTHOFF, G. \& BAUERLE, R. H. (1970). Mutations creating internal promoter elements in the tryptophan operon of Salmonella typhimurium. Journal of Molecular Biology 49, 171-196.

YANOFSKY, C. \& LENNOX, E. S. (1959). Transduction and recombination study of linkage relationships among the genes controlling tryptophan synthesis in Escherichia coli. Virology 8, 425-447. 